\title{
PERSEPSI MASYARAKAT TERHADAP SIKAP DISIPLIN PERANGKAT DESA SENAKIN KABUPATEN LANDAK
}

\author{
Erna Octavia ${ }^{1}$, Billy Harmento ${ }^{2}$ \\ ${ }^{1,2}$ Program Studi PPKn Fakultas Ilmu Pendidikan dan Pengetahuan Sosial \\ IKIP PGRI Pontianak Jalan Ampera Nomor 88 Pontianak 78116 \\ Email : erna8649@yahoo.co.id
}

\begin{abstract}
Abstrak
Masyarakat merupakan sekelompok orang yang membentuk sebuah sistem semi tertutup dan semi terbuka dimana sebagian besar interaksi adalah antara individu-individu yang berada dalam kelompok tersebut, masyarakat adalah berkumpul, bersama dengan saling mempengaruhi (Abdul Syani 2007 :15). Masyarakat madani merupakan tujuan masyarakat yang ingin dicapai oleh masyarakat Indonesia yakni masyarakat yang beradad, menjunjung tinggi nilai-nilai kemanusiaan, yang maju dalam penguasaan ilmu pengetahuan dan teknologi, masyarakat madani dapat berdiri secara mandiri dihadapan penguasa dan Negara, yang memiliki ruang publik dalam mengemukakan pendapat, adanya lembaga-lembaga yang mandiri yang dapat mengeluarkan aspirasi dan kepentingan publik. Masyarakat atau warga Negara sebagai pendukung Negara dan memiliki arti penting bagi negara.Sebagai anggota dari Negara maka warga Negara memiliki hubungan ikatan dengan negara.
\end{abstract}

Kata Kunci : Persepsi, Masyarakat, Sikap Disiplin, Perangkat Desa.

\begin{abstract}
Society is a group of people who form a semi-closed and semi-open system where most interactions are between individuals who are in the group, the community is gathered together with mutual influence (Abdul Syani 2007: 15). Civil society is a community goal that Indonesian people want to achieve, namely a civilized society, upholding human values, advancing in the mastery of science and technology, civil society can stand independently before the authorities and the State, which has public space in expressing opinions, there are independent institutions that can issue public aspirations and interests. Society or citizens as supporters of the State and have important meaning for the country. As a member of the State, citizens have ties to the state
\end{abstract}

Keywords : Perception, Society, Discipline Attitude, Village Toolkit.

\section{PENDAHULUAN}

Kepala desa adalah pemimpin desa di Indonesia, Kepala desa merupakan pimpinan penyelengaraan pemerintahan desa berdasarkan kebijakan yang ditetapkan bersama Badan Permusyawaratan Desa (BPD) (PP No 57 Tahun 2005). Aparat sering diartikan sebagai pegawai negeri atau pegawai Negara atau seperangkat sistem yang digunakan oleh penguasa \pemerintah untuk mengelola kekuasaannya atau semua perangkat yang digunakan oleh pemerintah untuk menerapkan kekuasaan pada masyarakat.Oleh karena itu, seandainya aparat sebagai pegawai sekalipun maka tidak hanya meliputi pegawai yang berstatus pegawai negeri melainkan pegawai yang bukan pegawai negeri juga sepanjang terlibat dalam kegiatan pemerintahan.

Dalam Pasal 202 Undang-Undang No 32 Tahun 2004 Tentang Pemerintahan Daerah (UU Pemda) dinyatakan bahwa pemerintah desa terdiri atas kepala desa dan perangkat desa. Perangkat desa terdiri dari sekretaris desa, kepala dusun, rusun tetangga dan rukun warga. Dengan demikian dapat dikatakan bahwa aparat desa meliputi semua orang yang terlibat dalam urusan pemerintahan desa. Disiplin merupakan sikap, tingkah laku dan perbuatan yang sesuai dengan peraturan 
perusahaan baik yang tertulis maupun yang tidak tertulis. Disiplin kerja dapat didefinisikan sebagai suatu sikap menghormati, menghargai, patuh dan taat terhadap peraturan-peraturan yang berlaku, baik yang tertulis maupun tidak tertulis serta sanggup menjalankannya dan tidak menggelak untuk menerima sanksi-sanksinya apabila ia melanggar tugas dan wewenang yang diberikan kepadanya. Kedisiplinan merupakan keinginan dan kesadaran untuk mentaati peraturan organisasi dan norma sosial. Oleh karena itu disiplin merupakan saran penting untuk mencapai tujuan, maka pembinaan disiplin merupakan bagian dari manajemen yang sangat penting. Manajemen apa saja dalam pelaksanaannya memerlukan disiplin segenap anggota organisasi. Disiplin dikatakan juga sebagai sarana untuk melatih dan mendidik orang-orang terhadap peraturan-peraturan agar ada kepatuhan dan supaya dapat berjalan dengan tertip dan teratur dalam organisasi.

Menegakkan suatu kedisiplinan sangatlah, sebab kedisiplinan berisikan peraturanperaturan yang harus ditaati karyawan. Dengan kedisiplinan diharapkan dapat membuat pekerjaan seefisien mungkin.Disiplin kerja dapat dilihat sebagai sesuatu yang besar manfaatnya, baik bagi kepentingan organisasi maupun bagi para karyawan. Bagi organisasi adanya disiplin kerja akan menjamin terpeliharanya tata tertib dan kelancaran pelaksanaan tugas, sehingga diperoleh hasil yang optimal. Sedangkan bagi karyawan akan diperoleh suasana kerja yang menyenangkan sehingga akan menambah semangat kerja dalam melaksanakan pekerjaannya. Dengan demikian, karyawan dapat melaksanakan tugasnya dengan penuh kesadaran serta dapat mengembangkan tenaga dan pikirannya semaksimal mungkin demi terwujudnya tujuan organisasi.

Persepsi masyarakat terhadap kualitas pelayanan pemerintah secara umum berdasarkan kinerjanya masih belum seperti yang diharapkan oleh masyarakat. Hal ini dapat dilihat antara lain dari pengaduan atau keluhan dari masyrakat tentang pelayanan yang berbelit-belit, tidak transparan, kurang informasi, kurang akomodatif, kurang konsisten, terbatasnya fasilitas, sarana dan prasarana pelayanan, sehingga tidak menjamin kepastian hukum, waktu dan biaya serta masih banyak dijumpai praktek pungutan liar serta tindakan-tindakan yang berindikasi penyimpangan seperti korupsi, kolusi dan nepotisme. Mengacu pada beberapa uraian diatas buruknya pelayanan publik ini antara lain dikarenakan belum optimalnya transparansi dan akuntabilitas dalam penyelenggaraan pelayanan publik. Oleh karena itu, pelayanan publik harus dilaksanakan secara transparan dan akuntabel oleh setiap unit pelayanan instansi pemerintah, karena kualitas kinerja birokrasi pelayanan publik memiliki implikasi yang luas dalam mencapai kesejahteraan masyarakat. Hakikat pelayanan publik berdasarkan Keputusan Menteri Pendayagunaan Aparatur Negara (MenPAN) Nomor 63 Tahun 2004 adalah pemberian pelayanan prima kepada masyarakat yang merupakan perwujudan kewajiban aparatur pemerintah sebagai pelayan masyarakat. Hal 
pokok yang menjadi dasar perlunya otonomi daerah adalah pemerintah daerah harus dapat menyediakan pelayanan yang sesuai dengan keberhasilan masyarakat setempat. Hasil pra observasi penulis menemukan di Kantor Desa Senakin Kabupaten Landak hal yang benar-benar tampak yaitu mengenai disipilin terkadang masyarakat sudah datang di jam pagi namun pegawainya masih belum ada belum lagi ketidak jelasan informasi mengenai penyelesaian tiaptiap masalah yang ada di masyarakat. Berdasarkan uraian latar belakang diatas dan permasalahan diatas penulis mengangkat judul dengan "Persepsi Masyarakat Terhadap Sikap Disiplin Perangkat Desa Senakin Kabupaten Landak”

\section{METODE}

Metode penelitian kualitatif adalah "Metode yang berlandaskan pada filsafah postpositifisme, digunakan untuk meneliti objek yang alamiah, dimana peneliti adalah instrument kunci, pengambilan sampel dengan trianggulasi, analisis data bersifat induktif/kualitatif, dan hasil penelitian kualitatif lebih menekankan makna dari pada generalisasi" (Sugiono 2010 : 5). Dipilihnya metode kualitatif dalam penelitian ini karena dianggap tepat untuk menggungkap permasalahan-permasalahan yang terjadi dilapangan, masalah yang di maksud adalah Persepsi Masyarakat Terhadap Sikap Disiplin Perangkat Desa Senakin Kabupaten Landak. Bentuk yang digunakan dalam penelitian ini adalah deskriptif data yang terkumpul berupa kata-kata atau gambar.

Lokasi dalam penelitian ini dilaksanakan di Desa Senakin Kabupaten Landak tepatnya di Kantor desa tersebut. Dalam penelitian ini yang akan menjadi subjek penelitiannya adalah Kepala Desa, Kaur Pemerintah, Kaur Pembangunan, Kaur Pembangunan, Kaur Kesra, Kaur Keuangan, Kaur Umum, Kepala Dusun serta Staf Administrasi Desa serta masyarakat setempat.

\section{HASIL DAN PEMBAHASAN}

\section{Sikap Disiplin Perangkat Desa Senakin Dalam Pelayanan Dengan Masyarakat}

Sikap disiplin dikantor Desa Senakin dapat dilihat dari tata tertib kantor desa senakin sendiri, melakukan pekerjaan dengan penuh dengan penuh tanggung jawab, melakukan sesuatu tanpa ada paksaan dari siapapun dan taat dalam menjalankan tugas dan fungsi perangkat desa.

Masalah disiplin pegawai sangat penting artinya terutama dalam upaya percepatan dan meningkatkan mutu pelayanan kepada masyarakat. Oleh karena itu maka aparatur pemerintah sebagai motor penggerak pembangunan sudah selayaknya mempelopori masalah disiplin, mengingat tugas pokok, fungsi, dan tanggung jawab aparatur pemerintah yang sangat berat, rumit dan menentukan maka aparatur harus meningkatkan kemampuan dan kualitas yang tinggi dalam 
pelaksanaan tugas. Kedisiplinan berasal berasal dari kata latin "discipline" yang berarti latihan atau pendidikan kesopanan dan keharmonian serta pengembangan tabiat. Defenisi tersebut jelas sekali bahwa arah dan tujuan disiplin pada dasarnya adalah keharmonisan dan kewajaran, kehidupan kelompok, baik organisasi formal maupun non formal (Martoyo, 2000 : 151).

Kedisiplinan merupakan keadaan tertib dimana orang-orang yang tergabung dalam organisasi induk pada peraturan-peraturan yang telah ada dengan rasa senang hati. Kedisiplinan adalah suatu keadaan dimana seseorang mampu melakukan peraturan yang ada, agar kedisiplinan berjalan dengan baik seperti dalam berpakaian.disiplin mengikuti jam masuk, istirahat dan pulang, melaksanakan pekerjaan dengan penuh tanggung jawab, para pegawai tersebut hendaklah menjalankannya dengan penuh kesadaran (Martoyo, 2000 : 131).

Disiplin kerja adalah usaha yang dilaksanakan untuk menciptakan keadaan suatu lingkungan kerja yang tertib, berdaya guna dan berhasil guna melalui sistem pengaturan yang tepat (Moenir, 2002 :18). Selanjutnya (Rivai, 2006 : 444) mengatakan, disiplin kerja adalah suatu alat yang digunakan para pimpinan untuk berkomunikasi dengan pegawai agar mereka bersedia untuk mengubah suatu perilaku serta sebagai suatu upaya untuk meningkatkan kesadaran dan kesediaan seseorang mentaati semua peraturan perusahaan dan norma-norma sosial yang berlaku. Berdasarkan dari kutipan diatas, maka dapat disimpulkan bahwa kedisiplinan kerja adalah merupakan suatu keadaan yang tertib dan teratur, dimana orang-orang yang bergabung dalam wadah organisasi melaksanakan tugas-tugas dan tanggung jawabnya secara tertib, teratur dan disiplin sesuai dengan peraturan dan perundang-undangan yang berlaku atau di tetapkan dalam organisasi tersebut sehingga tidak ada yang melakukan pelanggaran terhadap peraturan yang telah ditetapkan tersebut.

Pemerintahan diartikan sebagai sekumpulan orang yang mengelola kewenangan, melaksanakan kepemimpinan, dan koordinasi pemerintah serta pembangunan masyarakat dari lembanga-lembaga tempat mereka bekerja. "Pemerintahan dalam arti luas adalah segala urusan yang dilakukan oleh negara dalam menyelenggarakan kesejahteraan rakyatnya dan kepentingan negara sendiri.” Menurut Jamaludin A.N (2015: 109).

Adapun fungsi pemerintahan desa menurut Rivai (Jamaludin A.N 2015: 111)" berupa segala sosial, karena harus di wujudkan dalam interaksi antara individu didalam situasi sosial kelompok masyarakat". Adapun fungsi pemerintahan desa secara optimal dapat dibedakan dalam fungsi pokok, sebagai berikut :
a. Instruktif
b. Konsultatif.
c. Partisipasi. 
d. Delegasi

e. Pengendalian

Dari berdasarkan hasil wawancara yang dilakukan peneliti dapat ditarik kesimpulan bahwa kinerja sikap disiplin perangkat desa sudah baik namun ada beberapa hal yang dilihat masih kurang, contohnya ketepatan waktu dalam bekerja masih ada yang dilihat datang terlambat, dalam hal pelayanan sudah baik terlihat dari alur mekanisme yang dibuat di kantor desa sudah sesuai, hal lain juga ditemukan peneliti di kantor desa senakin masih mengadakan pungutan liar meskipun tidak semua pegawai melakukannya namun dari hasil wawancara peneliti lakukan masyarakat menilai dengan memberikan pungutan liar tersebut akan lancar urusan dikantor desa. Berdasarkan hasil observasi diatas dapat disimpulkan peneliti melihat pegawai di kantor desa senakin sudah baik dalam melaksanakan sikap disiplin hal ini terbukti dengan mematuhi tata tertib di kantor desa senakin. Pegawai kantor desa senakin dalam melaksanakan tugas sudah penuh dengan tanggung jawab dengan penuh semangat tanpa ada rasa mengeluh dengan pekerjaan yang harus dilakukan setiap hari.

\section{Prosedur Yang Sesuai Pelayanan Di Perangkat Desa Senakin Dengan Masyarakat Setempat}

Nilai tanggung jawab ialah kesadaran manusia atas tingkah lakunya, berbuat sebagai perwujutan kesadaran akan kewajibannya. Beberapa hal yang terkait erat dengan pengertian tanggung jawab di antaranya adalah hak dan kewajiban, pengabdian, pengorbanan dan norma sosial. Salah satu jenis tanggung jawab adalah tanggung jawab terhadap Tuhan Yang Maha Esa. Setiap manusia ingin hidupnya di dunia berarti dan mempunyai kehidupan yang lebih baik di akhirat yang kekal. Oleh karena itu, setiap tindakannya berkaitan dengan tanggung jawab manusia sebagai upaya pencapaian tujuan tersebut. (Soetomo, 1995).

Tanggung jawab menurut kamus umum bahasa indonesia adalah keadaan wajib menanggung segala sesuatunya. Sehingga bertanggung jawab menurut kamus umum bahasa indonesia adalah berkewajiban menanggung, memikul jawab, menanggung segala sesuatunya atau memberikan jawab dan menanggung akibatnya. Tanggung jawab adalah kesadaran manusia akan tingkah laku atau perbuatannya yang disengaja maupun yang tidak disengaja. Tanggung jawab juga berarti berbuat sebagai wujudan kesadaran akan kewajibannya. Manusia pada hakikatnya adalah mahluk yang bertanggung jawab. Disebut demikian karena manusia, selain merupakan makhluk individual dan makhluk sosial, juga merupakan makhluk Tuhan. Manusia memiliki tuntutan yang besar untuk bertanggung jawab mengingat ia mementaskan sejumlah peranan dalam konteks sosial, individual ataupun teologis. 
Ridwan Halim (2005) mendefinisikan ”tanggung jawab hukum sebagai sesuatu akibat lebih lanjut dari pelaksaan peranan, baik peranan itu merupakan hak dan kewajiban ataupun kekuasaan." Secara umum tanggung jawab hukum diartikan sebagai kewajiban untuk melakukan sesuatu atau berprilaku menurut cara tertentu tidak menyimpang dari peraturan yang telah ada. Purbacaraka berpendapat bahwa tanggung jawab hukum bersumber atau lahir atas penggunaan fasilitas dalam penerapan kemampuan tiap orang untuk menggunakan hak atau/dan melaksanakan kewajibannya.

Manusia merupakan makhluk sosial, Ia tidak dapat hidup sendirian dengan perangkat nilainilai selera sendiri. Nilai-nilai yang diperankan seseorang dalam jaminan sosial harus dipertanggungjawabkan sehingga tidak mengganggu konsensus nilai yang telah disetujui bersama. Masalah tanggung jawab dalam konteks individual berkaitan dengan konteks teologis. Manusia sebagai makhluk individual artinya manusia harus bertanggung jawab terhadap dirinya (seimbangan jasmani dan rohani) dan harus bertanggung jawab terhadap Tuhannya (sebagai penciptanya). Tanggung jawab manusia terhadap dirinya akan lebih kuat intensitasnya apabila ia memiliki kesadaran yang mendalam. Tanggung jawab manusia terhadap dirinya juga muncul sebagai akibat keyakinannya terhadap suatu nilai. Demikian pula tanggung jawab manusia terhadap Tuhannya, manusia sadar akan keyakinan dan ajaran-Nya. Oleh karena itu manusia harus menjalankan perintah-Nya dan menjauhi larangan-Nya agar manusia dijauhkan dari perbuatan keji dan munkar.

Tanggung jawab dalam konteks pergaulan manusia adalah keberanian. Orang yang bertanggung jawab adalah orang yang berani menanggung resiko atas segala yang menjadi tanggung jawabnya. Ia jujur terhadap dirinya dan jujur terhadap orang lain, tidak pengecut dan mandiri. Dengan rasa tanggung jawab, orang yang bersangkutan akan berusaha melalui seluruh potensi dirinya. Selain itu juga orang yang bertanggung jawab adalah orang yang mau berkorban demi kepentingan orang lain. Tanggung jawab juga berkaitan dengan kewajiban. Kewajiban adalah sesuatu yang dibebankan terhadap seseorang. Kewajiban merupakan bandingan terhadap hak dan dapat juga tidak mengacu kepada hak. Maka tanggung jawab dalam hal ini adalah tanggung jawab terhadap kewajibannya. Orang yang bertanggung jawab dapat memperoleh kebahagiaan, karena orang tersebut dapat menunaikan kewajibannya. Kebahagiaan tersebut dapat dirasakan oleh dirinya atau orang lain. Sebaliknya, jika orang yang tidak bertanggung jawab akan menghadapi kesulitan karena ia tidak mengikuti aturan, norma, atau nilai-nilai yang berlaku. Problema utama yang dirasakan pada zaman sekarang sehubungan dengan masalah tanggung jawab adalah berkaratnya atau rusaknya perasaan moral dan rasa hormat diri terhadap pertanggung jawaban. 
Manusia itu berjuang memenuhi keperluannya sendiri atau untuk keperluan pihak lain. Untuk itu ia akan menghadapi manusia lain dalam masyarakat atau menghadapi lingkungan alam. Dalam usahanya itu manusia menyadari bahwa ada kekuatan lain yang ikut menentukan yaitu kekuasaan Tuhan. Dengan demikian tanggung jawab itu dapat dibedakan menurut keadaan manusia atau hubungan yang dibuatnya. Atas dasar ini, dikenal jenis-jenis atau macam-macam dari tanggung jawab.

a. Tanggung Jawab manusia terhadap diri sendiri

b. Tanggung Jawab kepada masyarakat

c. Tanggung Jawab kepada Bangsa/Negara

d. Tanggung Jawab kepada Tuhan

Berdasarkan hasil wawancara yang dilakukan oleh peneliti dengan narasumber tekait dengan prosedur yang sesuai pelayanan di perangkat desa senakin dengan masyarakat setempat dapat diuraikan sebagai berikut dalam tabel 4.4 :

\begin{tabular}{|c|l|l|}
\hline No & \multicolumn{1}{|c|}{ Nama Responden } & \multicolumn{1}{|c|}{ Hasil Wawancara } \\
\hline 1 & Kaur Pembangunan (ardi) & $\begin{array}{l}\text { Prosedur yang baik yaitu harus sesuai dengan } \\
\text { aturan yang berlaku dan kemudian staf } \\
\text { dikantor desa harus ramah dengan semua } \\
\text { kalangan masyarakat dan tidak memihak atau } \\
\text { memprioritaskan orang yang lebih penting, } \\
\text { tentunya tidak meminta biaya tambahan } \\
\text { pungutan liar). }\end{array}$ \\
\hline 2 & Kasi Pemerintahan (susana) & $\begin{array}{l}\text { Pelayanan yang ramah serta penjelasan yang } \\
\text { betul dapat dijadikan acuan dalam melayani } \\
\text { masyarakat. }\end{array}$ \\
\hline 3 & Kepala Desa (mandiro) & $\begin{array}{l}\text { Sejauh ini dikantor desa sudah sangat baik } \\
\text { dalam melayani karena alur yang dibuat sudah } \\
\text { cukup sangat jelas. }\end{array}$ \\
\hline 5 & Ketua RT 5 & $\begin{array}{l}\text { Prosedur yang baik prosedur yang sesuai } \\
\text { dengan aturan yang dibuatnya yaitu melayani } \\
\text { masyarakat dengan baik. }\end{array}$ \\
\hline 7 & Ketua RT 8 & $\begin{array}{l}\text { Pelayanan yang baik menurut saya yaitu hak, } \\
\text { wewenang dan kewajiban masyarakat sudah } \\
\text { dipenuhi oleh kantor desa. }\end{array}$ \\
\hline 8 & Ketua RT 7 & $\begin{array}{l}\text { Menurut saya pelayanan sesuai prosedur yang } \\
\text { baik adalah pelayanan yang tidak ada } \\
\text { pungutan liarnya (pungli). }\end{array}$ \\
\hline
\end{tabular}




\begin{tabular}{|c|c|c|}
\hline & & $\begin{array}{l}\text { apabila syaratnya sudah lengkap dari pihak } \\
\text { masyarakat akan dilayani dengan baik., } \\
\text { namun terkadang ada biaya tambahan yang } \\
\text { diminta sebesar sepuluh ribu rupiah. Contoh } \\
\text { pelayanan yang dilayani oleh pegawai desan } \\
\text { senakin diantaranya : Pelayanan kartu } \\
\text { keluarga, Pelayanan ktp, Pelayanan surat } \\
\text { pindah, Pelayanan akta kelahiran, Pelayanan } \\
\text { surat kematian, Pelayanan surat keterangan } \\
\text { lain (pengajuan perizinan, SKU, SIU \& } \\
\text { NPWP, Surat ijin kerja, SKCK, Surat nikah. }\end{array}$ \\
\hline 9 & Syukur (masyarakat desa senakin) & $\begin{array}{l}\text { Mengenai prosedur pelayanan sudah } \\
\text { diarasakan dengan baik dan tidak bertele-tele } \\
\text { apabila syaratnya sudah lengkap dari pihak } \\
\text { masyarakat akan dilayani dengan baik., } \\
\text { namun terkadang ada biaya tambahan yang } \\
\text { diminta sebesar sepuluh ribu rupiah. Contoh } \\
\text { pelayanan yang dilayani oleh pegawai desan } \\
\text { senakin diantaranya : Pelayanan kartu } \\
\text { keluarga, Pelayanan ktp, Pelayanan surat } \\
\text { pindah, Pelayanan akta kelahiran, Pelayanan } \\
\text { surat kematian, Pelayanan surat keterangan } \\
\text { lain (pengajuan perizinan, SKU, SIU \& } \\
\text { NPWP, Surat ijin kerja, SKCK, Surat nikah. }\end{array}$ \\
\hline 10 & Yakobus (masyarakat desa senakin) & $\begin{array}{l}\text { Mengenai prosedur pelayanan sudah } \\
\text { diarasakan dengan baik dan tidak bertele-tele } \\
\text { apabila syaratnya sudah lengkap dari pihak } \\
\text { masyarakat akan dilayani dengan baik., } \\
\text { namun terkadang ada biaya tambahan yang } \\
\text { diminta sebesar sepuluh ribu rupiah. Contoh } \\
\text { pelayanan yang dilayani oleh pegawai desan } \\
\text { senakin diantaranya : Pelayanan kartu } \\
\text { keluarga, Pelayanan ktp, Pelayanan surat } \\
\text { pindah, Pelayanan akta kelahiran, Pelayanan } \\
\text { surat kematian, Pelayanan surat keterangan } \\
\text { lain (pengajuan perizinan, SKU, SIU \& } \\
\text { NPWP, Surat ijin kerja, SKCK, Surat nikah. }\end{array}$ \\
\hline 11 & Nikolas (masyarakat desa senakin) & $\begin{array}{l}\text { Mengenai prosedur pelayanan sudah } \\
\text { diarasakan dengan baik dan tidak bertele-tele } \\
\text { apabila syaratnya sudah lengkap dari pihak } \\
\text { masyarakat akan dilayani dengan baik., } \\
\text { namun terkadang ada biaya tambahan yang } \\
\text { diminta sebesar sepuluh ribu rupiah. Contoh } \\
\text { pelayanan yang dilayani oleh pegawai desan } \\
\text { senakin diantaranya : Pelayanan kartu } \\
\text { keluarga, Pelayanan ktp, Pelayanan surat } \\
\text { pindah, Pelayanan akta kelahiran, Pelayanan } \\
\text { surat kematian, Pelayanan surat keterangan }\end{array}$ \\
\hline
\end{tabular}




\begin{tabular}{|c|c|c|}
\hline & & $\begin{array}{l}\text { lain (pengajuan perizinan, SKU, SIU \& } \\
\text { NPWP, Surat ijin kerja, SKCK, Surat nikah. }\end{array}$ \\
\hline 12 & Robin (masyarakat desa senakin) & $\begin{array}{l}\text { Mengenai prosedur pelayanan sudah } \\
\text { diarasakan dengan baik dan tidak bertele-tele } \\
\text { apabila syaratnya sudah lengkap dari pihak } \\
\text { masyarakat akan dilayani dengan baik., } \\
\text { namun terkadang ada biaya tambahan yang } \\
\text { diminta sebesar sepuluh ribu rupiah. Contoh } \\
\text { pelayanan yang dilayani oleh pegawai desan } \\
\text { senakin diantaranya : Pelayanan kartu } \\
\text { keluarga, Pelayanan ktp, Pelayanan surat } \\
\text { pindah, Pelayanan akta kelahiran, Pelayanan } \\
\text { surat kematian, Pelayanan surat keterangan } \\
\text { lain (pengajuan perizinan, SKU, SIU \& } \\
\text { NPWP, Surat ijin kerja, SKCK, Surat nikah. }\end{array}$ \\
\hline 13 & Lisa (masyarakat desa senakin) & $\begin{array}{l}\text { Mengenai prosedur pelayanan sudah } \\
\text { diarasakan dengan baik dan tidak bertele-tele } \\
\text { apabila syaratnya sudah lengkap dari pihak } \\
\text { masyarakat akan dilayani dengan baik., } \\
\text { namun terkadang ada biaya tambahan yang } \\
\text { diminta sebesar sepuluh ribu rupiah. Contoh } \\
\text { pelayanan yang dilayani oleh pegawai desa } \\
\text { senakin diantaranya : Pelayanan kartu } \\
\text { keluarga, Pelayanan ktp, Pelayanan surat } \\
\text { pindah, Pelayanan akta kelahiran, Pelayanan } \\
\text { surat kematian, Pelayanan surat keterangan } \\
\text { lain (pengajuan perizinan, SKU, SIU \& } \\
\text { NPWP, Surat ijin kerja, SKCK, Surat nikah. }\end{array}$ \\
\hline
\end{tabular}

Sumber : Peneliti 2019

Desa merupakan ujung tombak pelaksanaan kebijakan pemerintahan masyarakat. Sebagai representasi kehadiran negara, desa adalah garda terdepan yang berhubungan langsung dengan rakyat. Dari hasil wawancara diatas yang dilakukan peneliti dapat menyimpulkan bahwa pelayanan sudah dilakukan dengan baik dan sesuai dengan prosedur yang ada, prosedur disini yaitu sesuai dengan tata tertib serta aturan yang berlaku dikantor desa itu sendiri dan ini merupakan kesimpulan hasil wawancara dari pegawai kantor desa senakin. Sedangkan hasil wawancara dengan masyarakat setempat masyarakat masih merasakan adanya pungutan liar yang dianggap tidak sesuai dengan tata tertib prosedur pelayanan di desa senakin sendiri. Mengenai kelengkapan dari masyarakat dalam mengurus hal di kantor desa senakin sudah lengkap dna hanya tinggal diproses namun terkadang masih di perlambat karena faktor pungli tersebut. Sedangkan bentuk pelayanan dikantor desa tersebut diantaranya Pelayanan kartu keluarga, Pelayanan ktp, Pelayanan surat pindah, Pelayanan akta kelahiran, Pelayanan surat kematian, Pelayanan surat keterangan lain (pengajuan perizinan, SKU, SIU \& NPWP, Surat ijin kerja, SKCK, Surat nikah. 


\section{SIMPULAN}

Sikap disiplin dapat diukur dengan melihat tata tertib di kantor desa dengan aturan-aturan yang ada, melakukan pekerjaan dengan penuh tanggung jawab, melakukan sesuatu tanpa ada paksaan dari siapapun dan taat dalam bekerja. Perangkat desa sebagian besar sudah melaksanakan aturan-aturan dengan tertib seperti kehadiran pulang, jadwal pemakaian seragam kerja, cara pelaksanaan kerja dalam melayani masyarakat setempat, dan pelayanan sudah dilakukan dengan baik dan sesuai dengan prosedur yang ada, prosedur disini yaitu sesuai dengan tata tertib serta aturan yang berlaku dikantor desa itu sendiri. Dari pernyataan tersebut terlihat bahwa efektivitas pelayanan akan dipengaruhi oleh disiplin aparat itu sendiri hal ini yang dimaksud adalah staf kantor desa, apabila sudah disiplin tentunya dalam hal melayani pastinya akan baik.

\section{DAFTAR PUSTAKA}

Abdul Syani. 2007. Sosiologi Skematika, Teori, dan Terapan. Jakarta : PT. Bumi. Aksara Martoyo, Susilo. 2000. Manajemen Sumber Daya Manusia. Jogjakarta: PT BPFE

Moenir. 2002. Maanajemen Pelayanan Umum di Indonesia. Jakarta: PT. Bumi. Aksara.

Rivai Zainal, Veithzal dkk, 2014, Kepemimpinan dan Perilaku Organisasi, Raja. Grafindo Persada, Jakarta

Sugiyono. 2010. Metode Penelitian Pendidikan Pendekatan Kuantitatif, kualitatif, dan R\&D. Bandung: Alfabeta.

PP No 57 Tahun 2005

Pasal 202 UU No 32 Tahun 2004

PP Menpan No 63 Tahun 2004 